\title{
Joseph Fourier
}

The Man and the Physicist

\section{John Herivel}

Fourier was not only a great mathematician and physicist but also played an important part in the Revolution in his native town of Auxerre. This book gives the first account of his life based on all the available primary and secondary material; it also examines the hitherto largely ignored physical aspects of the Analytical Theory of Heat. Illustrated $£ 9.75$

\section{The Religion of Isaac Newton}

The Fremantle Lectures 1973

\section{Frank E. Manuel}

This book stresses the historical and scriptural character of Newton's religion and its emotional intensity. The metaphysical problems of science and religion are presented in this context. The work is based to a considerable extent upon newly available manuscripts that were once part of the Portsmouth Collection and are now housed in the Jewish National and University Library in Jerusalem. $£ 3.50$

\section{Providence Lost}

A Critique of Darwinism Richard Spilsbury

'This book questions the facile notions which we have inherited from the 19 th century and which are still with us, perpetuated by the popular media. Mr. Spilsbury thinks ahead of our age and writes imaginatively. His objections to Neo-Darwinism will, I think, appeal to the young whose minds have not yet been conditioned by the pseudo-scientific propaganda.'-Jerzy Peterkiewicz $£ 3.50$

\begin{tabular}{l}
\hline Autobiographies \\
\hline Charles Darwin and T.H. Huxley \\
\hline Edited by Sir Gavin de Beer
\end{tabular}

Darwin's Autobiography is a classic written by a genius about a genius. The autobiographical writings of T.H. Huxley, 'Darwin's Bulldog', are less well known but they provide invaluable information about his self-education and early hardships. The juxtaposition of Darwin's and Huxley's memoirs in one volume pinpoints their similarities and differences, and illuminates the relationship between them. Illustrated £3.30 Oxford English Memoirs and Travels

\section{Oxford University Press}




\section{THE PROBLEM OF LIFE: AN ESSAY ON THE ORIGINS OF BIOLOGICAL THOUGHT}

\section{- C.U.M. Smith}

What is Life? This is a question which thinkers have asked themselves since classical times. C.U.M. Smith, Senior Lecturer in Biology at the University of Aston in Birmingham, charts the course of what is now seen as a biological science from its broader based origins. The Greeks attempted to explain inanimate nature in terms considered by thinkers today to be more appropriate to biological and physiological phenomena. Yet contempory interpretations which treat the mind as a subtle and complex machine have much in common with the theories of centuries ago. This introductory text is ideally suited to students of science and philosophy with its comprehensive bibliography and list of sources. It points out that the problem of Life is a subject of continuing debate which cannot afford to ignore its past.

$£ 10.00$

For further details/inspection copies please write to Anne Calcott, The Macmillan Press, Little Essex Street, London WC2R 3LF

\section{MACMILLAN PRESS}

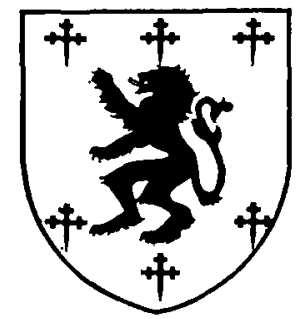

\section{MICHAEL PHELPS \\ ANTIQUARIAN BOOKS \\ 203 Upper Richmond Road West, London SW14 8QT \\ 8784699}

Specialising in all aspects of

\section{The History of Science \& Medicine}

\section{Catalogue available-send 75 pence}

Wants list gratefully received and given careful attention

Binding and the restoration undertaken

Books always needed 


\section{The British Society for the History of Science}

TrE object of the Society is to further the study of the history of science by holding meetings for the reading and discussion of papers and by facilitating the publication of relevant material. The British Journal for the History of Science is published by the Society as its official organ.

There will generally be a summer meeting, a winter meeting, and an Easter meeting of the Society. Additional meetings are arranged for specific occasions such as important anniversaries.

Membership, which includes a subscription to The British fournal for the History of Science, is open to all persons approved by the Council of the Society and elected at an ordinary meeting. The annual subscription is $£ 7.00$ ( $\$ 2$ r.00) or, for Students, $£ 3.00$ ( $\$ 9.00)$.

Membership: Applications for membership should be made on a form that is available from The Assistant Secretary, The British Society for the History of Science, 47 Belgrave Square, London SWIX 8QX.

\section{THE BRITISH JOURNAL FOR THE HISTORY OF SGIENCE}

THe Fournal is published three times a year, in March, July, and November, and the three parts published in any one year constitute a volume.

Editorial matters: Papers for inclusion in the fournal should be submitted to the Hon. Editor, Dr Robert Fox, Department of History, University of Lancaster, Bailrigg, Lancaster LAI $4 \mathrm{YG}$, from whom instructions may be obtained concerning the presentation and documentation of papers. All communications on editorial matters, and books for review, should be addressed to the Hon. Editor.

Advertising: Particulars about advertising in the Fournal may be obtained from The Advertisement Manager, The Institute of Physics, 47 Belgrave Square, London SWIX 8QX (or-235-6III).

Orders and back issues: Orders for the Fournal and inquiries about back issues should be addressed to Headley Brothers Ltd, Ashford, Kent TN24 $8 \mathrm{HH}$. Claims for missing copies should be made to Headley Brothers within six months of publication. Journal subscriptions for 1976 are now being booked at $£ 10.00(\$ 30.00)$.

(C) The British Society for the History of Science 1975. 


\section{The British Journal}

\section{for the}

\section{History of Science}

July 1975

Volume VIII Part 2 No. 29

Zev Brchler: 'A Less Agreeable Matter'-The Disagreeable Case of Newton and Achromatic Refraction

$101-126$

RosaleEn Love: Revisions of Descartes's Matter Theory in Le Monde

W. E. K. Middleton: Science in Rome, 1675-170o, and the Accademia Fisicomatematica of Giovanni Giustino Ciampini

ERIG Mendoza: A Critical Examination of Herapath's Dynamical Theory of Gases

Essay Reviews:

Thomas Hobbes's De Homine

166-169

Coulomb

$170-173$

Book Reviews

$174-189$

Books Received

190-191

Inquiry

192

Notes on Contributors

Published by

The British Society for the History of Science

Registered Ofice: 47 Belgrave Square, London SWIX $8 Q X$

Price: $\mathbf{£} 3.50$ or $\$ 10.50$ including postage (Free to members of the Society)

Brit. J. Hist. Sei. 8 No. 29 Published July 1975 